\title{
DYNAMIKA I KIERUNKI ROZWOJU SUBURBANIZACJI REZYDENCJALNEJ W AGLOMERACJI POZNANSKIEJ
}

\begin{abstract}
Zarys treści Celem artykułu jest rozpoznanie głównych cech rozwoju budownictwa mieszkaniowego w aglomeracji poznańskiej (Poznań i 17 gmin powiatu poznańskiego). Tu najwcześniej z obszarów wielkomiejskich w Polsce (za wyjątkiem Łodzi), zaczął się proces depopulacji miasta centralnego, któremu towarzyszy lawinowy wzrost liczby mieszkańców w gminach ościennych. Główną tego przyczyną są migracje rezydencjalne mieszkańców Poznania do strefy podmiejskiej, które nasiliły się szczególnie po 2004 roku. W pracy przedstawiono szacunki rozwoju terenów mieszkaniowych aglomeracji na podstawie lokalnych studiów planistycznych. Wykazano znaczne przeszacowanie chłonności terenów przeznaczonych pod budownictwo mieszkaniowe w stosunku do prognoz demograficznych.
\end{abstract}

Słowa kluczowe Suburbanizacja, budownictwo mieszkaniowe, zmiany demograficzne, planowanie przestrzenne.

\section{Wprowadzenie}

Suburbanizacja to proces przenoszenia form przestrzennych miasta oraz życia miejskiego na tereny otaczające rdzeń miejski oraz proces zespalania funkcjonalnego obszarów podlegających suburbanizacji z miastem centralnym (Lisowski, Grochowski 2008). W węższym aspekcie suburbanizacja to proces decentralizacji $\mathrm{w}$ regionie miejskim polegający na przemieszczaniu się ludności i podmiotów gospodarczych z miasta centralnego do strefy podmiejskiej. Szczególną formą suburbanizacji jest rozlewanie się miasta (urban sprawl), które oznacza proces zagospodarowywania terenów wiejskich często w żywiołowy i niekontrolowany sposób, prowadząc do chaosu przestrzennego i degradacji krajobrazu. Zagospodarowanie to cechuje rozproszona lokalizacja domostw, usług oraz miejsc pracy, często o niewystarczającej infrastrukturze komunikacyjnej i uzależnieniu od transportu indywidualnego (Rebernik 2005; Stanilov 2007). 
Do końca lat 80 . XX w. miasta socjalistyczne wyraźnie odróżniały się od miast Europy Zachodniej. Cechowała je zwartość przestrzenna, kompaktowość, większa gęstość zaludnienia, większy udział terenów przemysłowych i słabo wykształcona strefa podmiejska (Hirt 2008). Związane to było z publiczną własnością przestrzeni miejskich, koncentracją ludności w budowanych w tym okresie osiedlach bloków mieszkalnych. Po 1989 roku w miastach postsocjalistycznych zaczęły się przekształcenia związane $\mathrm{z}$ wprowadzeniem gospodarki wolnorynkowej, wykształceniem się rynku nieruchomości, zmianami w użytkowaniu ziemi oraz szeregiem zmian społecznych (m.in. wzrostem poziomu wykształcenia ludności, wzrostem dysproporcji w poziomie dochodów i rozwojem klasy średniej), co z kolei wpłynęło na zmiany przestrzenne, a w szczególności na procesy przenoszenia ludności i podmiotów gospodarczych poza obszar miasta centralnego (Kurek i in. 2014).

Od ostatniej dekady ubiegłego stulecia, duże aglomeracje miejskie w krajach Europy Środkowo-Wschodniej wykazują bardzo silną dynamikę zmian funkcjonalno-przestrzennych. Procesy te przebiegają w różny sposób w poszczególnych krajach, a także różnicują się w ich obrębie (Hamilton i in. 2005; Stanilov 2007; Hirt 2013). W Polsce, w obliczu liberalnego prawa planistycznego, większość nowych potencjałów pojawiających się na obszarach aglomeracji nie wydaje się być podporządkowana systemowo zarządzanym procesom integracji przestrzennej czy funkcjonalnej i stanowi wynik działań pojedynczych podmiotów i ich aktywności. Przynosi to zdecydowanie korzyści ekonomiczne, często jednak o doraźnym charakterze, gdzie koniunktura, np. na nieruchomości niezabudowane, przemienia się w problemy ich zagospodarowania, połączenia medialnego czy skomunikowania transportem publicznym.

Celem artykułu jest przedstawienie tempa oraz kierunków rozwoju terenów mieszkaniowych w aglomeracji poznańskiej. Realizacja tego celu polegała na diagnozie stanu istniejącego i dynamiki budownictwa mieszkaniowego oraz na identyfikacji polityk przestrzennych samorządów aglomeracji w odniesieniu do terenów mieszkaniowych. W wymiarze przestrzennym, licząca około 1 mln mieszkańców aglomeracja poznańska stanowi niezwykle dynamiczny układ kształtowany przez proces intensywnej suburbanizacji. Przejawia się on depopulacją miasta centralnego na rzecz strefy podmiejskiej, w której postępuje zanik funkcji rolniczej oraz rozwój terenów mieszkaniowych, komunikacyjnych i terenów pod działalność gospodarczą. Jednym z uderzających zjawisk, charakterystycznych tak dla całej Polski, jak i dla aglomeracji poznańskiej, jest wyjątkowo silna tendencja do realizowania nowego budownictwa na terenach dotąd nieobjętych aktywnościami inwestycyjnymi, przy jednoczesnym sporadycznym podejmowaniu recyclingu przestrzeni w obszarach miejskich. 


\section{Czynniki rozwoju mieszkalnictwa w strefie podmiejskiej}

Budownictwo mieszkaniowe i warunki mieszkaniowe uznawane są za istotny wskaźnik pokazujący poziom zaawansowania procesów suburbanizacyjnych. $\mathrm{Na}$ warunki zamieszkania ludności składa się cały wachlarz zagadnień opisujących mieszkania, budynki, a także ich otoczenie. Ta problematyka w literaturze przedmiotu określana jest często mianem środowiska mieszkaniowego (Suliborski 1976). Przyczyn niedorozwoju budownictwa mieszkaniowego można upatrywać w braku środków materialno-technicznych, czego wyrazem jest deficyt mieszkań w stosunku do liczby gospodarstw domowych, a także w pewnym niedoborze skutecznych instrumentów organizacyjnych, w tym krajowych i lokalnych programów wspierających budownictwo mieszkaniowe. Warto zwrócić uwagę na fakt, że polityka mieszkaniowa jest elementem także polityk publicznych i ma nie tylko sektorowy charakter, ale także przestrzenny. W planowaniu przestrzennym kluczową rolę odgrywa planowanie terenów pod inwestycje, w tym w szczególności inwestycje mieszkaniowe. Gminna polityka przestrzenna w Polsce oparta jest na obligatoryjnym dokumencie - Studium uwarunkowań i kierunków zagospodarowania przestrzennego. Poszczególne gminy określają w nim przeznaczenie swoich terenów na konkretne funkcje. Jedną z podstawowych jest funkcja mieszkaniowa. Polityka przestrzenna jest zatem istotnym elementem polityki mieszkaniowej.

Rozwój społeczno-gospodarczy na terenie aglomeracji poznańskiej, obserwowany szczególnie w ostatniej dekadzie, zintensyfikował procesy urbanizacyjne. Ich rezultatem jest silny rozwój budownictwa mieszkaniowego. Suburbanizacja od dawna przebiega w bliskiej strefie podmiejskiej Poznania (pierwszy pierścień gmin), ale od kilkunastu lat, szczególnie po 2004 roku, zaczyna obejmować także kolejne, drugie od granic Poznania, pasmo gmin powiatu poznańskiego.

Powstanie gęsto zaludnionej strefy podmiejskiej wokół Poznania jest rezultatem działania sił dekoncentracji (Parysek 2008). Determinują ją, tak jak w przypadku wielu innych polskich miast, czynniki technologiczne, ekonomiczne i społeczne (zob. m.in. Liszewski 1987; Chmielewski 2005; Jeżak 2005; Bagiński 2006; Lisowski, Grochowski 2008; Brzeziński 2010).

Czynniki technologiczne umożliwiają łatwy i relatywnie szybki kontakt z odległymi przestrzennie terenami, co wynika z tworzenia nowych układów komunikacyjnych (autostrady, drogi ekspresowe, obwodnice miast), rozwoju środków transportu, szczególnie motoryzacji indywidualnej i rozwoju środków łączności (telefon, komputer). Czynniki ekonomiczne wyrażają się z jednej strony wysokością renty gruntowej, preferującej lokalizację miejsc zamieszkania poza granicami miasta, z drugiej zaś wyczerpywaniem się terenów pod budownictwo w mieście centralnym. Czynniki społeczne przejawiają się we wzroście zamożności 
i wykształcenia większej grupy mieszkańców, która realizuje potrzebę poprawy warunków zamieszkania, poprzez przenoszenie się poza granice miasta. Fakt ten wzmacniany jest argumentem nowoczesności (nowoczesne, a nawet luksusowo wyposażone domy), statusem społecznym (przynależność do klasy lepiej zarabiających) oraz stylem życia (obcowanie z otwartą przestrzenią, bliskość terenów zielonych), preferowanym nawet za cenę oddalenia od miejsc pracy i usług.

Zjawisku intensywnej suburbanizacji sprzyja brak systemowej i skoordynowanej polityki przestrzennej $\mathrm{w}$ gminach (co wynika także $\mathrm{z}$ uwarunkowań prawnych) oraz dążenie deweloperów do zagospodarowania terenów łatwiej dostępnych, a tym samym umożliwienie swobodnego zaspokajania potrzeb mieszkaniowych, przy dominujących preferencjach dla „,domu z ogródkiem” (Więcław-Michniewska 2006; Raźniak, Winiarczyk 2014). Skutkiem silnej suburbanizacji jest relokacja miejsc zamieszkania i rosnąca skala przemieszczeń ludności w zakresie dojazdów do pracy, do szkół i po usługi, co widać w całej jaskrawości między Poznaniem a gminami powiatu poznańskiego. Obszar powiatu poznańskiego wraz z miastem Poznań zaczął tworzyć zwartą przestrzennie aglomerację wielkomiejską. Jest to także poszerzający się rynek mieszkaniowy, który przy rosnącej sile nabywczej mieszkańców daje możliwości realizacji coraz to bardziej wyszukanych potrzeb mieszkaniowych: od kamienic i bloków, po szeregowce, osiedla domków jednorodzinnych i luksusowe rezydencje, odizolowane od zwartej zabudowy.

„Wylanie" się miasta poza granice administracyjne przypomina rozbudowę dużych polskich miast w latach 70 . XX w. Wtedy to, za rozwojem osiedli, a nawet całych dzielnic wielorodzinnego budownictwa mieszkaniowego (w Poznaniu: Rataje i Piątkowo) nie nadążały (ze względu na brak środków) inwestycje w infrastrukturę transportową, techniczną, a w szczególności społeczną (Kaczmarek, Mikuła 2012). Ta swoista „hipersuburbanizacja” dotyka obecnie także gminy powiatu poznańskiego. W ślad za rozwojem budownictwa mieszkaniowego i rosnącą liczbą mieszkańców nie nadąża realizacja potrzeb komunalnych - budowa dróg, sieci wodno-kanalizacyjnej oraz placówek usług publicznych, szczególnie oświatowych. Z tymi problemami zmagają się władze lokalne silnie urbanizujących się gmin powiatu poznańskiego.

Suburbanizacja od dawna przebiegała w bliskiej strefie podmiejskiej Poznania (miejscowości przy granicach miasta), ale od kilkunastu lat zaczęła obejmować także kolejne, drugie od granic Poznania pasmo gmin powiatu poznańskiego. Poznań jako miejsce zamieszkania konkuruje więc nie tylko z innymi dużymi miastami kraju, ale także z okolicznymi gminami. Rynek mieszkaniowy aglomeracji poznańskiej należy rozpatrywać zarówno w kontekście konkurencyjności, jak i komplementarności. Cechy rynku mieszkaniowego w mieście centralnym, na jego obrzeżach, w miastach satelitarnych oraz na terenach wiejskich są 
zgoła odmienne, czego najlepszym przejawem jest zróżnicowana cena działek budowlanych, a w ślad za tym, budowanych domów i mieszkań. Cena ta sięga od 600-1000 zł za m² w Poznaniu do 30-60 zł z m² w gminach położonych 30-50 km od miasta, np. Buk czy Murowana Goślina (Koncepcja kierunków rozwoju przestrzennego Metropolii Poznań, 2016). Całościowe ujmowanie aglomeracji poznańskiej jako jednego rynku mieszkaniowego wydaje się koniecznym podejściem, choćby z racji silnych powiązań migracyjnych, usługowych, rynku pracy, transportowych i administracyjnych między Poznaniem a siedemnastoma gminami powiatu poznańskiego.

\section{Dynamika rozwoju i formy budownictwa mieszkaniowego}

W okresie intensywnej suburbanizacji w latach 2005-2014, w strefie podmiejskiej Poznania (gminach powiatu poznańskiego) oddano do użytku 36016 nowych mieszkań z ogólnej liczby 67744 w całej aglomeracji (56\%). Przekłada się to na ponad $4,2 \mathrm{mln} \mathrm{m}^{2}$ nowej zabudowy mieszkaniowej, czyli $64 \%$ dla całej aglomeracji.

$\mathrm{W}$ analizowanej dekadzie ujawnił się wyraźny trend wzrostowy w zakresie rozwoju mieszkalnictwa, który wyjątkową dynamikę osiągnął szczególnie w latach 2008-2012 (ryc. 1). W porównaniu do 2367 nowych mieszkań oddanych w powiecie poznańskim w 2006 roku, liczba 4535 nowych mieszkań w 2008 roku i 4324 w 2011 roku była prawie dwukrotnie wyższa. Dane dla 2011 roku wskazują, że po lekkim osłabieniu dynamiki w latach 2009-2010, w powiecie ponownie osiągnięty został wynik powyżej 4 tys. nowych mieszkań rocznie (4324). Interesujące wydaje się zestawienie wyżej przytoczonych liczb z ich odpowiednikami dla miasta Poznania. Do 2007 roku w mieście powstawało więcej mieszkań niż w powiecie, jednak od 2008 roku tendencja ta trwale się odwróciła. W 2011 roku zanotowano rekordową przewagę nowo oddanych do użytku mieszkań w powiecie w porównaniu do miasta (4324 do 2512 czyli o $72 \%$ więcej). W 2014 roku liczba nowo oddanych mieszkań w mieście - 3642 po raz pierwszy od 6 lat przewyższyła liczbę nowych mieszkań w powiecie (3318).

W strukturze budownictwa mieszkaniowego w powiecie poznańskim w latach 2005-2014 dominowała forma budownictwa indywidualnego (w zasadzie wyłącznie jednorodzinnego), w ramach której wybudowano 59,8\% nowych mieszkań. W systemie deweloperskim (czyli z przeznaczeniem na sprzedaż lub wynajem) powstało 36,5\% nowych lokali. Pozostała część przypada na budownictwo spółdzielcze, komunalne i czynszowe (TBS). Są to proporcje wyraźnie inne niż w przypadku miasta Poznania, gdzie w tym samym okresie w systemie deweloperskim powstało aż 77,4\% mieszkań, a w budownictwie indywidualnym zaledwie 17,2\% (tab. 1). 


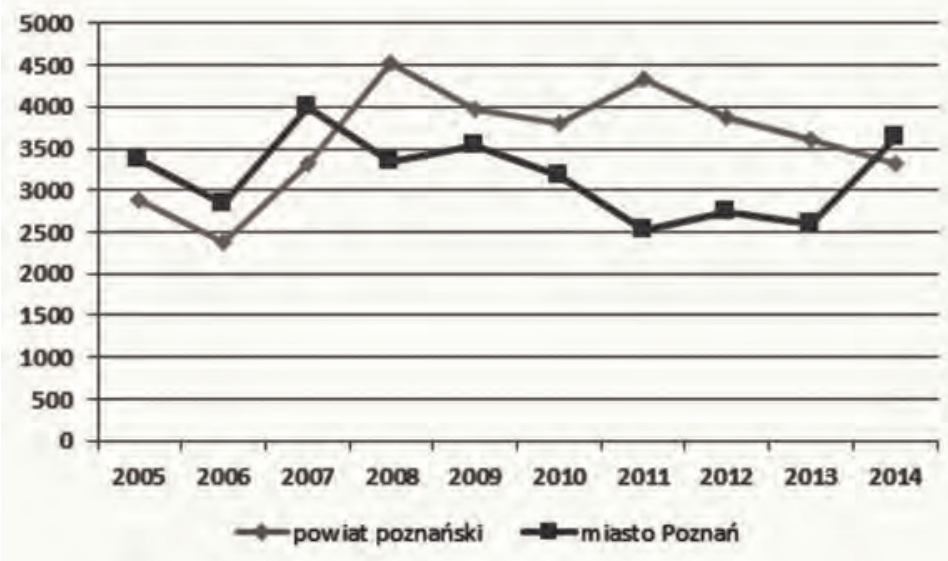

Ryc. 1. Liczba nowo oddanych do użytku mieszkań w aglomeracji poznańskiej

Źródło: opracowanie własne na podstawie danych GUS

Tabela 1

Liczba nowo oddanych mieszkań według form budownictwa w aglomeracji poznańskiej w latach 2005-2014

\begin{tabular}{lcccccc}
\multirow{2}{*}{$\begin{array}{c}\text { Forma } \\
\text { budownictwa }\end{array}$} & \multicolumn{2}{c}{ Aglomeracja ogółem } & \multicolumn{2}{c}{ Powiat poznański } & \multicolumn{2}{c}{ Poznań } \\
\cline { 2 - 7 } & $\begin{array}{c}\text { Liczba } \\
\text { mieszkań }\end{array}$ & $\%$ & $\begin{array}{c}\text { Liczba } \\
\text { mieszkań }\end{array}$ & $\%$ & $\begin{array}{c}\text { Liczba } \\
\text { mieszkań }\end{array}$ & $\%$ \\
\hline Ogółem & 67744 & 100,0 & 36016 & 100,0 & 31728 & 100,0 \\
\hline Deweloperskie & 37714 & 55,7 & 13151 & 36,5 & 24563 & 77,4 \\
\hline Indywidualne & 26985 & 39,8 & 21530 & 59,8 & 5455 & 17,2 \\
\hline Pozostałe & 3045 & 4,5 & 1335 & 3,7 & 1710 & 5,4 \\
\hline
\end{tabular}

Źródło: opracowanie własne na podstawie danych GUS

W ujęciu dynamicznym w powiecie poznańskim wyraźnie uwidacznia się dominująca rola budownictwa indywidualnego. Od 2008 roku dynamika budownictwa indywidualnego i deweloperskiego jest mniej więcej wyrównana, a w 2011 roku ich udział w liczbie nowo oddanych mieszkań na moment nawet się zrównał. Systematycznie w ostatnich latach maleje natomiast znaczenie wszystkich pozostałych form budownictwa (ryc. 2).

Forma organizacyjna budownictwa w istotny sposób oddziałuje na przeciętną wielkość nowo oddanego do użytku mieszkania. W całym analizowanym okresie średni wskaźnik dla powiatu poznańskiego był zdecydowanie wyższy niż w Poznaniu i przyjął wartość 117 m², jednak w przypadku budownictwa deweloperskiego wyniósł on $78 \mathrm{~m}^{2}$, a indywidualnego - $145 \mathrm{~m}^{2}$. Przeciętna powierzchnia 


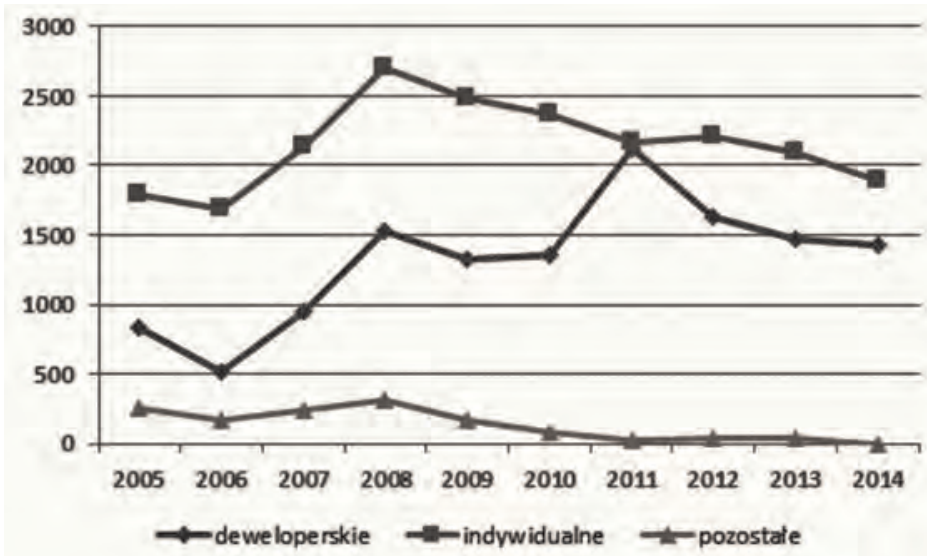

Ryc. 2. Liczba nowo oddanych do użytku mieszkań według form budownictwa w powiecie poznańskim w latach 2005-2014

Źródło: opracowanie własne na podstawie danych GUS

nowego mieszkania w budownictwie indywidualnym, odpowiadajaca w zasadzie średniej powierzchni nowego domu jednorodzinnego, wydaje się od kilku lat stosunkowo ustabilizowana. W przypadku budownictwa deweloperskiego, w powiecie poznańskim zauważalny jest powolny wzrost powierzchni oddawanych mieszkań od 2011 roku. Ma on związek nie tylko z większą powierzchnią mieszkań w budynkach wielorodzinnych, ale także z wejściem przedsiębiorców na rynek budownictwa jednorodzinnego (ryc. 3).

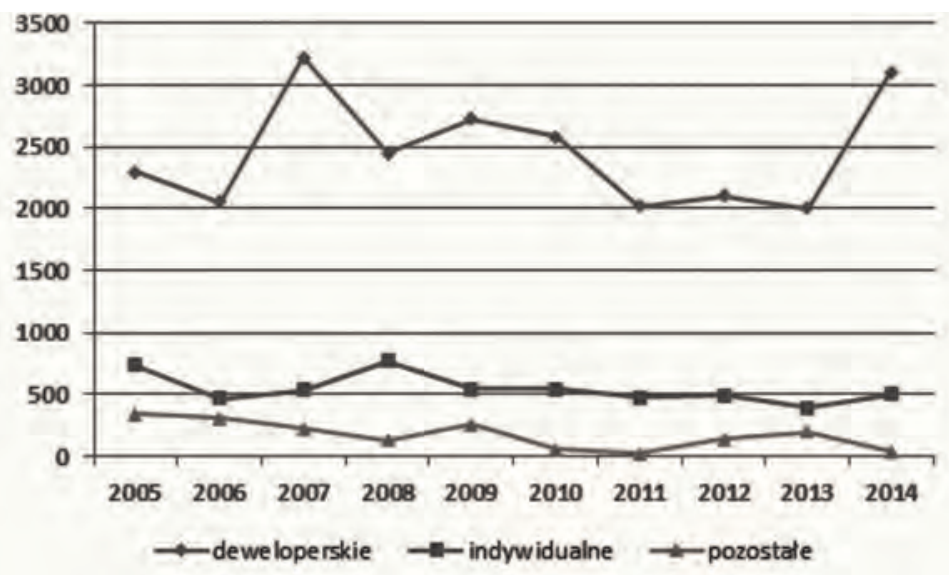

Ryc. 3. Liczba nowo oddanych do użytku mieszkań według form budownictwa w Poznaniu w latach 2005-2014

Źródło: opracowanie własne na podstawie danych GUS 
W najbardziej intensywnie rozwijających się pod względem mieszkaniowym gminach takich, jak Komorniki, Swarzędz, Dopiewo powstało w latach 2005-2014 ponad 4 tys. nowych mieszkań (ryc. 4, tab. 2). Na drugim końcu zestawienia znajdują się Buk i Puszczykowo. Liczba nowych mieszkań nie przekroczyła tam w analizowanym okresie pół tysiąca. Równie istotne są różnice między poszczególnymi gminami w zakresie przeciętnej powierzchni mieszkania oraz formy organizacyjnej budownictwa. Największe mieszkania w analizowanym okresie powstawały w gminach Puszczykowo (średnio $191 \mathrm{~m}^{2}$ ) i Tarnowo Podgórne $\left(149 \mathrm{~m}^{2}\right)$, najmniejsze w Luboniu $\left(88 \mathrm{~m}^{2}\right)$ i Komornikach $\left(97 \mathrm{~m}^{2}\right)$. Jednakże nawet w tym ostatnim przypadku jest to wskaźnik wyższy od miasta Poznania $\left(76 \mathrm{~m}^{2}\right)$.

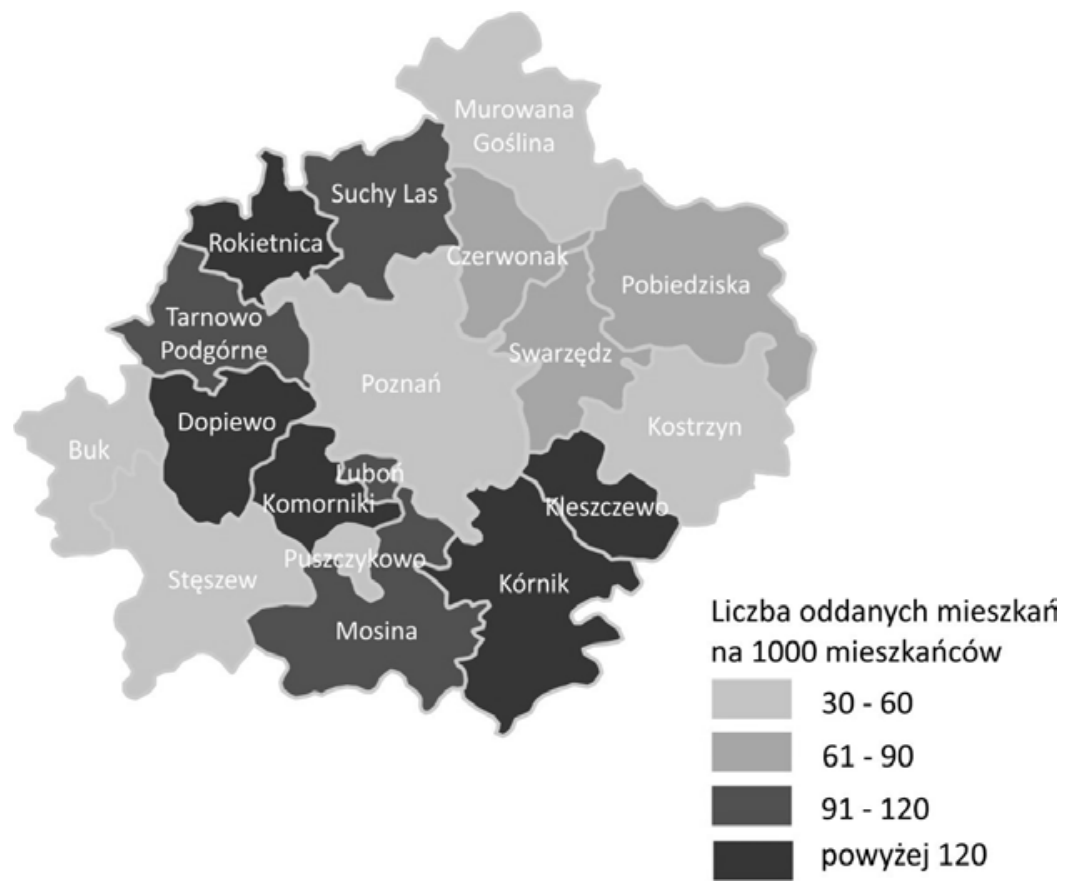

Ryc. 4. Liczba oddanych mieszkań na 1000 mieszkańców w gminach aglomeracji poznańskiej w latach 2005-2014

Źródło: opracowanie własne na podstawie danych GUS

W zakresie formy organizacyjnej budownictwa, należy zwrócić uwagę na ponadprzeciętny udział lokali deweloperskich w niektórych gminach intensywnie rozwijających się mieszkaniowo (szczególnie Komorniki i Luboń - powyżej 60\%), choć żadna gmina powiatu nie osiąga takich proporcji jak miasto Poznań (77\%). Z kolei w takich gminach, jak Buk, Puszczykowo i Pobiedziska zdecydowana większość nowych mieszkań powstaje w systemie indywidualnym (ponad 90\%). Z kolei w gminach: Czerwonak i Murowana Goślina, dużą rolę w omawianej dekadzie odegrało budownictwo spółdzielcze i społeczne czynszowe (TBS) (tab. 2). 
Tabela 2

Nowo oddane do użytku mieszkania w aglomeracji poznańskiej w latach 2005-2014

\begin{tabular}{|c|c|c|c|c|c|c|}
\hline Jednostka terytorialna & $\begin{array}{l}\text { Liczba } \\
\text { mieszkań }\end{array}$ & $\begin{array}{c}\text { Po- } \\
\text { wierzch- } \\
\text { nia } \\
\text { użytkowa } \\
\text { w m² }\end{array}$ & $\begin{array}{c}\text { Średnia } \\
\text { po- } \\
\text { wierzch- } \\
\text { nia } \\
\text { użytkowa } \\
\text { w m }^{2} \\
\end{array}$ & $\begin{array}{c}\text { \% miesz- } \\
\text { kań } \\
\text { w sy- } \\
\text { stemie } \\
\text { dewelo- } \\
\text { perskim }\end{array}$ & $\begin{array}{c}\text { \% miesz- } \\
\text { kań } \\
\text { w budow- } \\
\text { nictwie } \\
\text { indywidu- } \\
\text { alnym }\end{array}$ & $\begin{array}{c}\text { \% miesz- } \\
\text { kań w po- } \\
\text { zostałych } \\
\text { formach } \\
\text { budowni- } \\
\text { ctwa }\end{array}$ \\
\hline Poznań & 31728 & 2403293 & 76 & 77 & 17 & 6 \\
\hline Powiat poznański & 36016 & 4208898 & 117 & 37 & 60 & 3 \\
\hline Luboń & 2845 & 249855 & 88 & 61 & 35 & 4 \\
\hline Puszczykowo & 399 & 76161 & 191 & 5 & 95 & 0 \\
\hline Buk & 387 & 57043 & 147 & 0 & 100 & 0 \\
\hline Buk (M) & 134 & 17795 & 133 & 0 & 100 & 0 \\
\hline Buk (W) & 253 & 39248 & 155 & 0 & 100 & 0 \\
\hline Czerwonak & 1848 & 203180 & 110 & 9 & 55 & 36 \\
\hline Dopiewo & 4053 & 486347 & 120 & 39 & 61 & 0 \\
\hline Kleszczewo & 929 & 109901 & 118 & 33 & 60 & 7 \\
\hline Komorniki & 5318 & 514386 & 97 & 66 & 34 & 0 \\
\hline Kostrzyn & 997 & 125953 & 126 & 16 & 84 & 0 \\
\hline Kostrzyn (M) & 520 & 58972 & 113 & 27 & 73 & 0 \\
\hline Kostrzyn (W) & 477 & 66981 & 140 & 4 & 96 & 0 \\
\hline Kórnik & 3127 & 406057 & 130 & 25 & 73 & 2 \\
\hline Kórnik (M) & 573 & 58815 & 103 & 36 & 64 & 0 \\
\hline Kórnik (W) & 2554 & 347242 & 136 & 22 & 76 & 2 \\
\hline Mosina & 2747 & 292144 & 106 & 39 & 58 & 3 \\
\hline Mosina (M) & 665 & 80823 & 122 & 31 & 69 & 0 \\
\hline Mosina (W) & 2082 & 211321 & 101 & 42 & 54 & 4 \\
\hline Murowana Goślina & 767 & 93557 & 122 & 12 & 65 & 23 \\
\hline Murowana Goślina (M) & 480 & 50675 & 106 & 17 & 47 & 36 \\
\hline Murowana Goślina (W) & 287 & 42882 & 149 & 3 & 97 & 0 \\
\hline Pobiedziska & 1189 & 165337 & 139 & 6 & 93 & 1 \\
\hline Pobiedziska (M) & 419 & 52783 & 126 & 18 & 82 & 0 \\
\hline Pobiedziska (W) & 770 & 112554 & 146 & 0 & 99 & 1 \\
\hline Rokietnica & 2576 & 295828 & 115 & 26 & 74 & 0 \\
\hline Stęszew & 610 & 82076 & 135 & 12 & 88 & 0 \\
\hline Stęszew (M) & 297 & 39172 & 132 & 23 & 77 & 0 \\
\hline Stęszew (W) & 313 & 42904 & 137 & 1 & 99 & 0 \\
\hline Suchy Las & 1661 & 243335 & 146 & 23 & 77 & 0 \\
\hline Swarzędz & 4086 & 438089 & 107 & 47 & 51 & 2 \\
\hline Swarzędz (M) & 1511 & 132029 & 87 & 59 & 35 & 6 \\
\hline Swarzędz (W) & 2575 & 306060 & 119 & 40 & 60 & 0 \\
\hline Tarnowo Podgórne & 2477 & 369649 & 149 & 24 & 73 & 3 \\
\hline
\end{tabular}

Objaśnienia: $\mathrm{M}$ - miasto, $\mathrm{W}$ - obszar wiejski

Źródło: opracowanie własne na podstawie danych GUS 


\section{Warunki mieszkaniowe w aglomeracji poznańskiej}

W aglomeracji poznańskiej, według stanu na koniec 2014 roku, znajdowało się blisko 117,5 tys. budynków mieszkalnych, w których mieściło się ponad 365 tys. mieszkań o łącznej powierzchni $27,5 \mathrm{mln} \mathrm{m}^{2}$ (tab. 3). W powiecie poznańskim, według stanu na koniec 2014 roku, znajdowało się blisko 76 tys. budynków mieszkalnych, w których mieściło się ponad 117 tys. mieszkań o łącznej powierzchni $11,5 \mathrm{mln} \mathrm{m}^{2}$. Gminy powiatu skupiają $65 \%$ ogólnej liczby budynków mieszkalnych w aglomeracji poznańskiej, aczkolwiek posiadają mniejszy udział w łącznej liczbie i powierzchni mieszkań w aglomeracji - odpowiednio 32\% i 42\%. Różnice te wynikają z odmiennego charakteru zabudowy w powiecie poznańskim (głównie jednorodzinnej) i w mieście Poznaniu (przewaga zabudowy wielorodzinnej).

Średnia liczba mieszkań przypadająca na jeden budynek mieszkalny w powiecie poznańskim wynosi 1,5 , podczas gdy w Poznaniu - 6,0, a średni wskaźnik dla aglomeracji - 3,3. Wartość tego wskaźnika większą niż 2,0 osiągają gminy powiatu ze stosunkowo wyższym udziałem zabudowy wielorodzinnej: Czerwonak, Luboń, Swarzędz i Murowana Goślina. Gminami o największej dominacji zabudowy jednorodzinnej są Tarnowo Podgórne, Puszczykowo, Dopiewo, Rokietnica, Mosina i Stęszew (średnia liczba mieszkań na budynek mieszkalny 1,1-1,3).

Tabela 3

Zasoby mieszkaniowe w aglomeracji poznańskiej (2014)

\begin{tabular}{|c|c|c|c|c|c|c|c|}
\hline $\begin{array}{l}\text { Jednostka } \\
\text { terytorialna }\end{array}$ & $\begin{array}{c}\text { Budynki } \\
\text { mieszkal- } \\
\text { ne }\end{array}$ & $\begin{array}{l}\text { Mieszka- } \\
\text { nia }\end{array}$ & $\begin{array}{l}\text { Powierz- } \\
\text { chnia } \\
\text { użytkowa } \\
\text { mieszkań } \\
\text { w m² }\end{array}$ & $\begin{array}{c}\text { Średnia } \\
\text { liczba } \\
\text { mieszkań } \\
\text { w budyn- } \\
\text { ku }\end{array}$ & $\begin{array}{l}\text { Średnia } \\
\text { liczba } \\
\text { osób na } \\
\text { mieszka- } \\
\text { nie }\end{array}$ & $\begin{array}{c}\text { Średnia } \\
\text { powierz- } \\
\text { chnia } \\
\text { mieszka- } \\
\text { nia w m² }\end{array}$ & $\begin{array}{c}\text { Średnia } \\
\text { powierz- } \\
\text { chnia } \\
\text { miesz- } \\
\text { kalna na } \\
\text { osobę } \\
\text { w m }^{2}\end{array}$ \\
\hline $\begin{array}{l}\text { Aglomeracja } \\
\text { ogółem }\end{array}$ & 117533 & 365291 & 27559022 & 3,1 & 2,5 & 75,4 & 30,5 \\
\hline Poznań & 41630 & 247741 & 16015178 & 6,0 & 2,2 & 64,6 & 29,3 \\
\hline $\begin{array}{l}\text { Powiat } \\
\text { poznański }\end{array}$ & 75903 & 117550 & 11543844 & 1,5 & 3,1 & 98,2 & 32,2 \\
\hline
\end{tabular}

Źródło: opracowanie własne na podstawie danych GUS

Przeciętna powierzchnia mieszkania w powiecie poznańskim wynosi $98 \mathrm{~m}^{2}$ i jest znacząco wyższa od wskaźnika dla miasta Poznania $\left(65 \mathrm{~m}^{2}\right)$, a tym samym także średniej dla aglomeracji poznańskiej $\left(75 \mathrm{~m}^{2}\right)$. Stosunkowo niska przeciętna powierzchnia mieszkania występuje $\mathrm{w}$ gminach powiatu $\mathrm{z}$ wyższym udziałem zabudowy wielorodzinnej (Czerwonak, Luboń, Swarzędz i Murowana Goślina) 
i mieści się w przedziale $77-85 \mathrm{~m}^{2}$. Najwyższa przeciętna powierzchnia mieszkania charakteryzuje zamożniejsze gminy powiatu, z wysokim udziałem zabudowy jednorodzinnej takie, jak Tarnowo Podgórne (129 m²), Puszczykowo, Dopiewo, Suchy Las, Rokietnica, Kórnik, Komorniki (wszystkie w przedziale 102-120 m²).

Liczba osób przypadających na jedno mieszkanie w powiecie wynosi 3,05 i jest istotnie wyższa niż w przypadku miasta Poznania $(2,2)$. Tłumaczyć ten fakt można dwojako. Po pierwsze, znaczenie ma struktura demograficzna miasta w porównaniu do struktury ludności powiatu. W mieście wyższy jest udział osób starszych oraz młodych osób bezdzietnych, a tym samym gospodarstw domowych jedno- i dwuosobowych. Ponadto, istotna część mieszkań w Poznaniu może być zajmowana przez osoby bez meldunku w mieście (np. studentów), niewykazywanych w statystykach GUS. W większości gmin powiatu liczba osób przypadających na jedno mieszkanie przekracza 3, z wyjątkiem typowo miejskiego Lubonia $(2,7)$ i Komornik $(2,8)$, a także Swarzędza, Kórnika, Dopiewa i Suchego Lasu $(2,9)$.

Jednym z bardziej rozpowszechnionych wskaźników warunków mieszkaniowych jest przeciętna powierzchnia mieszkalna przypadająca na jednego mieszkańca. Wskaźnik ten wynosi dla powiatu $32,2 \mathrm{~m}^{2}$, co jest wartością wyższą od miasta Poznania $\left(29,3 \mathrm{~m}^{2}\right)$, wartości te są jednak prawdopodobnie statystycznie nieco zawyżone (w mieszkaniach - tak w gminach, jak i w Poznaniu - mieszka więcej osób niż liczba zameldowanych). W przypadku samego powiatu poznańskiego najniższą wartość wskaźnik przyjmuje dla gminy Czerwonak (poniżej $25 \mathrm{~m}^{2}$ na mieszkańca), a najwyższą dla gmin Tarnowo Podgórne, Dopiewo, Puszczykowo i Suchy Las (powyżej $39 \mathrm{~m}^{2}$ na mieszkańca).

\section{Kierunki rozwoju terenów mieszkaniowych w aglomeracji poznańskiej}

Podstawowym dokumentem określającym politykę przestrzenną miasta i gminy jest studium uwarunkowań i kierunków zagospodarowania przestrzennego. Studium nie jest aktem prawa miejscowego, ale jego ustalenia są wiążące dla organów gminy przy sporządzaniu miejscowych planów zagospodarowania przestrzennego. Wszystkie miasta i gminy aglomeracji poznańskiej posiadają obowiązujące studia uwarunkowań i kierunków zagospodarowania przestrzennego. $\mathrm{Na}$ ich podstawie w opracowaniu z 2016 roku Koncepcja kierunków rozwoju przestrzennego Metropolii Poznań (KKRPMP), dokonano oszacowania zasobu terenów inwestycyjnych o kierunkowym przeznaczeniu mieszkaniowym. Wzięto w nim pod uwagę tereny, na których możliwa jest realizacja funkcji mieszkaniowej: jednorodzinnej, wielorodzinnej oraz mieszanej mieszkaniowo-usługowej.

W skali całej aglomeracji poznańskiej przeznaczono w Studiach blisko 39 tys. ha terenów, na których może być realizowana funkcja mieszkaniowa. Pod względem powierzchni zdecydowanie najwięcej ich znajduje się w Poznaniu 
(9,5 tys. ha). W niektórych jednak gminach podmiejskich, powierzchnia planowanych terenów mieszkaniowych jest proporcjonalnie do liczby mieszkańców dużo większa i wynosi do 3 tys. ha (gminy: Dopiewo, Swarzędz, Kórnik). Większość pozostałych gmin pierwszego pierścienia aglomeracji wyznaczyło około 2 tys. ha terenów z funkcją mieszkaniową, nierzadko tę granicę istotnie przekraczając (Tarnowo Podgórne, Mosina, Komorniki, Czerwonak, Rokietnica). Do grupy tej zaliczyć można też jedną z gmin niesąsiadujących z Poznaniem - Pobiedziska, co wskazuje na to, że procesy intensywnej suburbanizacji w przyszłości mogą rozszerzyć swój zasięg przestrzenny. Pozostałe gminy drugiego pierścienia (Kostrzyn, Murowana Goślina, Stęszew, Buk) przeznaczają na cele mieszkaniowe w studiach powierzchnię około 1 tys. ha, mając nieco mniejsze ambicje przejęcia strumienia migracyjnego z Poznania w swoje granice. Do grupy tej można zaliczyć także gminy sąsiadujące z miastem centralnym - Suchy Las i Kleszczewo, przy czym w przypadku pierwszej, istotną rolę odgrywa specyfika struktury przestrzennej (większość obszaru gminy zajmuje poligon wojskowy). Gmina Kleszczewo ma natomiast w przeważającej części charakter rolniczy, uwarunkowany także dobrą jakością występujących tam gleb. Zestawienie zamykają niewielkie powierzchniowo gminy miejskie Luboń i Puszczykowo, gdzie szczególnie w przypadku Lubonia ograniczony zasób terenów jest w pewnej mierze rekompensowany intensywnością jego wykorzystania.

Pod względem udziału terenów mieszkaniowych w docelowej strukturze powierzchni gminy, miasta Luboń i Puszczykowo znajdują się, odwrotnie niż w poprzednim przypadku, na czele zestawienia (odpowiednio 57\% i 37\%). Miasto Poznań ze wskaźnikiem 36\% wyróżnia się wśród pozostałych gmin powiatu. Należy jednak zauważyć, że kilka gmin planuje udział terenów mieszkaniowych na poziomie bliskim 30\% (Swarzędz, Dopiewo, Komorniki, Tarnowo Podgórne), co w przypadku realizacji tych zamierzeń nadałoby im charakter silnie zurbanizowany, niewiele w zasadzie różniący się pod tym względem od miasta centralnego. W tym kontekście uwidaczniają się bardziej zachowawcze polityki gmin drugiego pierścienia, gdzie docelowy udział terenów mieszkaniowych z reguły oscyluje wokół $10 \%$, choć w niektórych przypadkach może to wynikać także z uwarunkowań przyrodniczych i obecności obszarów prawnie chronionych (m.in. Mosina, Murowana Goślina).

Jak wykazano w KKRPMP całościowo gminy aglomeracji poznańskiej posiadają w swoich granicach trzykrotnie więcej terenów o funkcji mieszkaniowej wyznaczonej w studiach gminnych niż samo miasto Poznań. Zagospodarowanie w ten sposób całego zasobu liczącego blisko 30 tys. ha nie wydaje się możliwe w perspektywie jednego czy nawet dwóch pokoleń. Sytuacja ta wpływa jednak w istotny sposób na kształtowanie się rynku nieruchomości w aglomeracji. Z perspektywy studiów gminnych podaż terenów o funkcji mieszkaniowej w strefie podmiejskiej jest praktycznie nieograniczona, biorąc pod uwagę możliwości 
prokreacyjne i ekonomiczne społeczeństwa. W zasadniczy sposób wpływa to na kształtowanie się cen gruntów w aglomeracji i decyzje inwestycyjne, zarówno profesjonalnych deweloperów, jak i indywidualnych gospodarstw domowych.

W Koncepcji kierunków zagospodarowania przestrzennego Metropolii Poznań (2016) oszacowano także, na podstawie przyjętych w studiach gminnych parametrów zabudowy, prognozowaną chłonność demograficzną terenów mieszkaniowych, tj. liczbę osób mogących zamieszkać na danym obszarze. Dla zabudowy mieszkaniowej jednorodzinnej brano pod uwagę wielkość działki budowlanej - zakładając, że na jednej działce może zostać zlokalizowany jeden budynek o funkcji mieszkaniowej. Dla zabudowy mieszkaniowej wielorodzinnej uwzględniono maksymalny procent powierzchni zabudowy działki budowlanej. Dla terenów o funkcji mieszanej, np. z zabudową usługową przyjęto, że 50\% powierzchni terenu zostanie zrealizowane pod funkcję mieszkaniową. Ponadto, dla obu rodzajów zabudowy przyjęto, że $30 \%$ powierzchni terenów zostanie przeznaczone pod lokalny układ komunikacji oraz zieleń towarzyszącą (szerzej na temat metodyki badań: Mikuła 2016). W zakresie przeciętnej liczby osób na 1 mieszkanie przyjęto wartości 2,29 dla Poznania i 3,06 dla powiatu, natomiast przeciętna powierzchnia użytkowa 1 mieszkania została ustalona $\mathrm{w}$ wielkości $64,8 \mathrm{~m}^{2}$ dla Poznania i $97 \mathrm{~m}^{2}$ dla powiatu. Obie pary wskaźników zaczerpnięto z Banku Danych Lokalnych GUS. Dane dotyczące prognozowanej chłonności w poszczególnych miastach i gminach przedstawiono w tab. 4.

Tabela 4

Chłonność demograficzna terenów przeznaczonych pod funkcję mieszkaniową na podstawie studiów uwarunkowań i kierunków zagospodarowania przestrzennego gmin

\begin{tabular}{lcccc}
\hline Jednostka terytorialna & $\begin{array}{c}\text { Prognozowana } \\
\text { chłonność } \\
\text { demograficzna } \\
\text { (os.) }\end{array}$ & $\begin{array}{c}\text { Aktualna } \\
\text { liczba } \\
\text { mieszkańców }\end{array}$ & $\begin{array}{c}\text { Prognozowana } \\
\text { chłonność } \\
\text { demograficzna } \\
\text { wskazanych } \\
\text { w studium } \\
\text { nowych terenów } \\
\text { mieszkaniowych }\end{array}$ & $\begin{array}{c}\text { Stosunek } \\
\text { prognozowanej } \\
\text { chłonności do } \\
\text { aktualnej liczby } \\
\text { mieszkańców }\end{array}$ \\
\hline Aglomeracja ogółem & 1658381 & 904574 & 753807 & 1,8 \\
\hline Poznań & 677732 & 545680 & 132052 & 1,2 \\
\hline Powiat poznański & 980649 & 358894 & 621755 & 2,7 \\
\hline
\end{tabular}

Źródło: Koncepcja kierunków zagospodarowania przestrzennego Metropolii Poznań (2016)

Z przedstawionych danych wynika, że całkowita liczba ludności, która mogłaby zamieszkać na terenach ze wskazaną w studiach gminnych funkcją mieszkaniową wynosi w przybliżeniu 1654 tys. osób, co oznaczałoby wzrost w stosunku 
do stanu aktualnego o około $84 \%$. Niezainwestowane dotąd tereny mieszkaniowe charakteryzują się chłonnością 754 tys. osób, z czego tylko 132 tys. (17,5\%) przypada na miasto Poznań. W przypadku zagospodarowania całości zasobu terenów mieszkaniowych wskazanych w studiach gminnych, ludność Poznania stanowiłaby zaledwie $41 \%$ mieszkańców aglomeracji (obecnie około $61 \%$ ).

W świetle aktualnych trendów demograficznych, możliwość wykorzystania całego zasobu terenów mieszkaniowych wyznaczonych w studiach gminnych w perspektywie nawet 20-30 lat wydaje się iluzoryczna. Przeszacowanie zapotrzebowania na nowe grunty pod budownictwo mieszkaniowe staje się jeszcze bardziej ewidentne, gdy zejdzie się z analizą na poziom gminny. Większość gmin aglomeracji, poza Poznaniem, Luboniem i Puszczykowem, wykazuje w swoich studiach potencjał pozwalający co najmniej na podwojenie aktualnej liczby mieszkańców. W przypadku ponad połowy gmin istnieje możliwość 3-4 krotnego powiększenia obecnej populacji, a w skrajnym przypadku gminy Pobiedziska wskaźnik ten jest 6-krotnie większy (Mikuła 2016). Do wykorzystania całego potencjału terenów mieszkaniowych wyznaczonych w studiach gminnych potrzebny byłby w praktyce lawinowy napływ migrantów spoza obszaru aglomeracji poznańskiej lub niewiarygodny wzrost stopy życiowej społeczeństwa, który przełożyłby się na kilkudziesięcioprocentowe zwiększenie przeciętnej powierzchni mieszkaniowej na osobę.

\section{Podsumowanie}

W opracowaniu przedstawiono tempo oraz kierunki rozwoju terenów mieszkaniowych w aglomeracji poznańskiej. Realizacja tego celu polegała na diagnozie stanu istniejącego i dynamiki budownictwa mieszkaniowego oraz na identyfikacji polityk przestrzennych samorządów aglomeracji w odniesieniu do terenów mieszkaniowych. Z przeprowadzonej diagnozy dotyczącej dynamiki rozwoju struktury mieszkalnictwa w aglomeracji poznańskiej wynikają następujące wnioski:

1. Analizowana dekada charakteryzowała się silnym rozwojem budownictwa mieszkaniowego w aglomeracji poznańskiej. W okresie tym liczba nowo oddanych mieszkań w Poznaniu i gminach powiatu była zbliżona. W latach 2005-2014 było to średnio po 3500 mieszkań rocznie.

2. Do 2007 roku w mieście powstawało więcej mieszkań niż w powiecie, jednak od 2008 roku tendencja ta się odwróciła. W okresie 2008-2013 o 10\% więcej mieszkań oddawano do użytku w strefie podmiejskiej, a w 2011 roku zanotowano rekordową przewagę nowo oddanych do użytku mieszkań w powiecie w porównaniu do miasta (4324 do 2512 czyli o $72 \%$ więcej).

3. Lata 2005-2014 można określić jako okres intensywnej suburbanizacji. W gminach powiatu poznańskiego oddano do użytku 36016 nowych miesz- 
kań z ogólnej liczby 67744 w całej aglomeracji (56\%). Przekłada się to na ponad $4,2 \mathrm{mln} \mathrm{m}^{2}$ nowej zabudowy mieszkaniowej, czyli $64 \%$ wyniku dla całej aglomeracji.

4. W strukturze budownictwa mieszkaniowego w powiecie poznańskim w latach 2005-2014 dominowała forma budownictwa indywidualnego (w zasadzie wyłącznie jednorodzinnego), w ramach której wybudowano 59,8\% nowych mieszkań. W systemie deweloperskim (czyli z przeznaczeniem na sprzedaż lub wynajem) powstało $36,5 \%$ nowych lokali. Są to proporcje wyraźnie inne niż w przypadku miasta Poznania, gdzie w tym samym okresie w systemie deweloperskim powstało aż 77,4\% mieszkań, a w budownictwie indywidualnym zaledwie $17,2 \%$.

5. Forma organizacyjna budownictwa w istotny sposób oddziałuje na przeciętną wielkość nowo oddawanego do użytku mieszkania. W całym analizowanym okresie średni wskaźnik dla miasta Poznania przyjął wartość $76 \mathrm{~m}^{2}$, podczas gdy dla gmin powiatu poznańskiego był zdecydowanie wyższy i wynosił $117 \mathrm{~m}^{2}$.

Obszar aglomeracji poznańskiej, złożony z miasta Poznania i 17 gmin powiatu poznańskiego, przekształca się od kilkunastu lat w spójny pod względem przestrzenno-funkcjonalnym organizm wielkomiejski, liczący obecnie ponad 900 tys. mieszkańców. Pod względem demograficznym aglomeracja rozwija się w sposób nierównomierny terytorialnie. Od 2000 roku ośrodek centralny - miasto Poznań ulega wyludnianiu, podczas gdy niemal wszystkie gminy powiatu (szczególnie wiejskie i miejsko-wiejskie) notują silny wzrost liczby ludności. Aglomeracja poznańska podlega silnemu procesowi suburbanizacji, w którym kluczową rolę, szczególnie po 2004 roku, odgrywają migracje z miasta na tereny podmiejskie. Jako cały obszar aglomeracja notuje od lat znaczny przyrost mieszkańców, a prognozy GUS zapowiadają podtrzymanie tej tendencji w najbliższych latach (do 2030 roku populacja aglomeracji poznańskiej ma zwiększyć się o 60 tys. osób).

Analizując polityki przestrzenne gmin aglomeracji poznańskiej stwierdzono przeszacowanie potrzeb $\mathrm{w}$ zakresie terenów zabudowy mieszkaniowej w stosunku do realiów demograficznych. Obszary z wyznaczoną w studiach uwarunkowań i kierunków zagospodarowania przestrzennego funkcją mieszkaniową obejmują powierzchnię blisko 40 tys. ha, czyli prawie $20 \%$ całej aglomeracji. Większość gmin podmiejskich planuje tereny mieszkaniowe o docelowej chłonności demograficznej kilkudziesięciu tysięcy osób, co łącznie dawałoby liczbę 1,6-1,7 mln mieszkańców aglomeracji. Tymczasem przy obecnej dynamice demograficznej aglomeracja poznańska w roku 2030 roku powinna liczyć około 1 mln mieszkańców. Nawet biorąc pod uwagę tendencje do poprawy warunków mieszkaniowych i wzrost wskaźnika powierzchni mieszkalnej na osobę należy stwierdzić, że pełne zagospodarowanie terenów przeznaczonych w studiach gminnych pod zabudowę mieszkaniową nie jest możliwe w perspektywie jednego, a nawet dwóch pokoleń. 
Oznacza to, że gminy skazują się na możliwość dalszej utraty kontroli nad swoim zagospodarowaniem przestrzennym. Każda inwestycja mieszkaniowa na terenach przeznaczonych na ten cel w studium, nawet jeśli powstaje w całkowitym oderwaniu od obszarów dotychczasowego zainwestowania i sieci infrastruktury, nie może bowiem zostać zablokowana interwencyjnym planem miejscowym.

Od lat w środowisku planistów i urbanistów postuluje się zintegrowanie lokalnego planowania przestrzennego w skali obszarów wielkomiejskich (metropolitalnych). Problem potrzeby zintegrowanych działań w aglomeracji poznańskiej dostrzeżony został już ponad 5 lat temu, czego efektem są zapisy Strategii rozwoju aglomeracji poznańskiej (2010). W osi strategicznej Gospodarka Przestrzenna i Środowisko, wśród koniecznych działań zwrócono uwagę na wypracowanie wspólnej koncepcji rozwoju przestrzennego aglomeracji poznańskiej, która wskazywałaby obszary priorytetowe dla rozwoju funkcji mieszkaniowych. Powinna ona uwzględniać potrzeby i możliwości rozwojowe aglomeracji, w tym w szczególności: analizy ekonomiczne, środowiskowe i społeczne, prognozy demograficzne, w tym uwzględniające, migracje do i w ramach aglomeracji, możliwości finansowania przez gminy: sieci komunikacyjnych i infrastruktury technicznej, a także infrastruktury społecznej, służących realizacji zadań własnych tych jednostek. Kluczowe znaczenie dla powodzenia bardziej racjonalnej polityki przestrzennej wobec mieszkalnictwa, ma przyjęcie nowych rozwiązań instytucjonalnych i prawnych, z przeniesieniem kompetencji ramowego planowania przestrzennego na poziom aglomeracji (obszaru metropolitalnego).

\section{LITERATURA}

Bagiński E., 2006, Suburbia jako wspótczesne formy osadnicze, [w:] Bagiński E. (red.), Sieć osadnicza jako przedmiot badań, Wrocław.

Brzeziński C., 2010, Procesy suburbanizacji obszarów podmiejskich na przykładzie gmin powiatu pabianickiego. Zmiany przestrzenne, „Acta Universitatis Lodziensis. Folia Oeconomica", 245, Łódź.

Chmielewski J.M., 2005, Suburbanizacja strefy metropolitalnej Warszawy, [w:] Lorens P. (red.), Integracja i dezintegracja obszarów metropolitalnych, Biblioteka Urbanisty, Warszawa.

Hamilton F.E., Dimitrovska Andrews K., Pichler-Milanovic (red.), 2005, Transformation of Cities in Central and Eastern Europe: Towards Globalization, United Nations University Press.

Hirt S.A., 2008, Stuck in the suburbs? Gendered perspectives on living at the edge of the post-communist city, „Cities”, 25, s. 340-354.

Hirt S.A., 2013, Whatever happened to the (post) socialist city?, „City”, 32, s. 29-38.

Jeżak J., 2005, Rozproszenie zabudowy bariera zrównoważonego rozwoju polskich metropolii - przyktad aglomeracji krakowskiej, [w:] Lorens P. (red.), Integracja i dezintegracja obszarów metropolitalnych, Biblioteka Urbanisty, Warszawa, s. 9-12. 
Kaczmarek T., Mikuła Ł., 2012, Budownictwo mieszkaniowe $w$ powiecie poznańskim, Kronika Powiatu Poznańskiego nr 3, Starostwo Powiatowe w Poznaniu, Poznań, s. 5-22. Koncepcja kierunków rozwoju przestrzennego Metropolii Poznań, 2016, Kaczmarek T., Mikuła Ł. (red.), Centrum Badań Metropolitalnych, Poznań.

Kurek S., Gałka J., Wójtowicz M., 2014, Wpływ suburbanizacji na przemiany wybranych struktur demograficznych $i$ powiązań funkcjonalno-przestrzennych $w$ Krakowskim Obszarze Metropolitalnym, Uniwersytet Pedagogiczny im. Komisji Edukacji Narodowej w Krakowie, Prace Monograficzne 724.

Lisowski A., Grochowski M., 2008, Procesy suburbanizacji - uwarunkowania, formy i konsekwencje, Materiały seminarium nt. Problematyka rozwoju obszarów miejskich, 28.02.2008, KPZK PAN, Warszawa.

Liszewski S., 1987, Strefa podmiejska jako przedmiot badan geograficznych. Próba syntezy, „Przegląd Geograficzny”, 59(1-2), PWN, Warszawa, s. 65-79.

Mikuła Ł., 2016, Planowanie rozwoju funkcji mieszkaniowych, produkcyjnych $i$ ustugowych, [w:] Mikuła Ł. (red.), Integracja planowania przestrzennego w Metropolii Poznań - problemy, metody, osiagnięcia, Biblioteka Aglomeracji Poznańskiej nr 27, Bogucki Wydawnictwo Naukowe, Poznań, s. 113-130.

Parysek J., 2008, Procesy suburbanizacji w aglomeracji poznańskiej, [w:] Kaczmarek T., Mizgajski A. (red.), Powiat Poznański. Jakość przestrzeni i jakość życia, Bogucki Wydawnictwo Naukowe, Poznań, s. 71-90.

Studium uwarunkowań rozwoju przestrzennego aglomeracji poznańskiej, 2012, Kaczmarek T. (red.), Centrum Badań Metropolitalnych UAM, Poznań.

Suliborski A., 1976, Środowisko mieszkaniowe jako przedmiot badań geografii osadnictwa, „Zeszyty Naukowe UŁ”, 2, Łódź: 7.

Strategia rozwoju aglomeracji poznańskiej. Metropolia Poznań 2020, 2011, Centrum Badań Metropolitalnych UAM, Poznań.

Raźniak P., Winiarczyk A., 2014, Warunki mieszkaniowe jako wymiar procesów suburbanizacji w wybranych obszarach metropolitalnych w Polsce, „Acta Geographica Silesiana", WNoZ UŚ, Sosnowiec, s. 73-82 .

Rebernik D., 2005, Urbanization trends and processes of population change in the Lubljana Urban Regionin the 1990s, „Geografia Polonica”, 78(1), s. 67-78.

Stanilov K., 2007, Housing trends in Central and Eastern European cities during and after the period of transition, [w:] Stanilov K. i in. (red.), The Post-Socialist City Urban Form and Space Transformations in Central and Eastern Europe after Socialism Series, „GeoJournal Library”, 92, s. 173-190.

Studium uwarunkowań rozwoju przestrzennego aglomeracji poznańskiej, 2012, Kaczmarek T., Mikuła Ł., Kaczmarek L. (red.), Centrum Badań Metropolitalnych UAM, Poznań.

Urban Sprawl in Europe: Landscape, Land-Use Change and Policy, 2007, Couch Ch., Petschel-Held G., Leontidou L. (red.), Wiley-Blackwell Publishing, Hoboken.

Więcław-Michniewska J., 2006, Krakowskie suburbia i ich społeczności, Instytut Geografii i Gospodarki Przestrzennej Uniwersytetu Jagiellońskiego, Kraków. 


\title{
DYNAMICS AND DIRECTIONS OF RESIDENTIAL SUBURBANIZATION IN THE POZNAŃ AGGLOMERATION
}

\begin{abstract}
The aim of the article is to identify the main characteristics and problems of housing development in the greater post-socialist city. The Poznan Agglomeration (Poznań and 17 communes of the Poznań), the earliest of the metropolitan areas in Poland (with the exception of Lodz), began the process of depopulation of the city center, accompanied by a dramatic increase in the number of inhabitants in neighboring municipalities. The main reason is migration of residents to Poznań suburban area, which intensified especially after 2004. The paper presents estimates of the development of urban residential areas on the basis of local planning studies. It has been shown a significant overestimation of the absorbency of land for housing in relation to demographic forecast.
\end{abstract}

Keywords Suburbanization, housing, demographic change, spatial planning.

Prof. dr hab. Tomasz Kaczmarek Instytut Geografii Społeczno-Ekonomicznej i Gospodarki Przestrzennej Wydział Nauk Geograficznych i Geologicznych Uniwersytet im. Adama Mickiewicza w Poznaniu e-mail: tomkac@amu.edu.pl 